\title{
Quality of life of nurse practitioners during the COVID-19 pandemic
}

\author{
Qualidade de vida dos profissionais de enfermagem durante a pandemia de COVID-19 \\ Calidad de vida de los profesionales de enfermería durante la pandemia del COVID-19
}

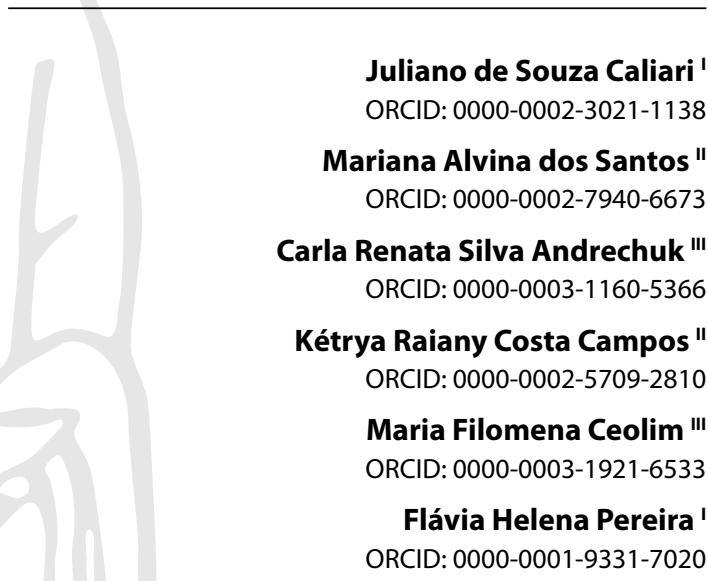

'Instituto de Educação, Ciência e Tecnologia do Sul de Minas Gerais. Passos, Minas Gerais, Brazil. "Universidade Federal do Mato Grosso do Sul. Três Lagoas, Mato Grosso do Sul, Brazil. "I Universidade Estadual de Campinas. Campinas, São Paulo,

Brazil.

How to cite this article: Caliari JS, Santos MA, Andrechuk CRS, Campos KRC, Ceolim MF, Pereira FH. Quality of life of nurse practitioners during the COVID-19 pandemic. Rev Bras Enferm. 2022;75(Suppl 1):e20201382. https://doi.org/10.1590/0034-7167-2020-1382

\section{Corresponding author: Juliano de Souza Caliari E-mail: juliano.caliari@ifsuldeminas.edu.br}

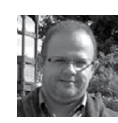

EDITOR IN CHIEF: Dulce Barbosa ASSOCIATE EDITOR: Elisabete Salvador

Submission: 01-26-2021

Approval: 05-09-2021

\begin{abstract}
Objective: to assess the quality of life of nurse practitioners during the COVID-19 pandemic and analyze related factors. Methods: cross-sectional and analytical study carried out with nurse practitioners. A questionnaire on sociodemographic characterization, work activities and changes perceived with the pandemic and WHOQOL-bref were used. To compare the groups of interest, analysis of covariance was used. Results: 572 professionals participated, who had a mean total quality of life score of 56.79 (SD=13.56). In the relationship of variables with WHOQOL-bref, having two or more jobs and being a nurse were associated with better quality of life, but being a woman and working more than 50 hours a week was associated with a worse perception of the construct. Conclusions: the factors analyzed indicate a lower perception of quality of life associated with the social domain, requiring interventions that reduce the damage to professionals' health and contribute to quality of care provided. Descriptors: Quality of Life; Nurse Practitioners; Pandemics; COVID-19; Health Surveys.
\end{abstract}

\section{RESUMO}

Objetivo: avaliar a qualidade de vida dos profissionais de enfermagem durante a pandemia de COVID-19 e analisar os fatores relacionados. Métodos: estudo transversal e analítico realizado com profissionais de enfermagem. Utilizaram-se questionário de caracterização sociodemográfica, atividades do trabalho e mudanças percebidas com a pandemia e WHOQOL-bref. Para comparar os grupos de interesse, adotou-se a análise de covariância. Resultados: participaram 572 profissionais, os quais apresentaram escore total médio de qualidade de vida de 56,79 ( $\mathrm{DP}=13,56)$. Na relação das variáveis com o WHOQOL-bref, ter dois ou mais vínculos de trabalho e ser enfermeiro estavam associados à melhor qualidade de vida, mas ser mulher e cumprir carga horária superior a 50 horas semanais associou-se à pior percepção do construto. Conclusões: os fatores analisados indicam menor percepção de qualidade de vida associados ao domínio social, sendo necessárias intervenções que reduzam os prejuízos à saúde dos profissionais e contribuam com a qualidade da assistência oferecida. Descritores: Qualidade de Vida; Profissionais de Enfermagem; Pandemias; COVID-19; Inquéritos Epidemiológicos.

\section{RESUMEN}

Objetivo: evaluar la calidad de vida de los profesionales de enfermería durante la pandemia del COVID-19 y analizar los factores relacionados. Métodos: estudio transversal y analítico realizado con profesionales de enfermería. Se utilizó un cuestionario sobre caracterización sociodemográfica, actividades laborales y cambios percibidos con la pandemia y WHOQOLbref. Para comparar los grupos de interés se utilizó el análisis de covarianza. Resultados: participaron 572 profesionales, quienes tuvieron una puntuación media de calidad de vida total de 56,79 (DE=13,56). En la relación de las variables con el WHOQOL-bref, tener dos o más trabajos y ser enfermera se asociaron a una mejor calidad de vida, pero ser mujer y trabajar más de 50 horas semanales se asoció a una peor percepción del constructo. Conclusiones: los factores analizados indican una menor percepción de la calidad de vida asociada al dominio social, requiriendo intervenciones que reduzcan el daño a la salud de los profesionales y contribuyan a la calidad de la atención brindada.

Descriptores: Calidad de Vida; Enfermeras Practicantes; Pandemias; COVID-19; Encuestas Epidemiológicas. 


\section{INTRODUCTION}

Coronavirus disease (COVID-19), first identified in China in December 2019, quickly spread throughout the world. In March 2020, it was considered a pandemic by the World Health Organization, affecting a variable level of severity, with important repercussions in terms of public health ${ }^{(1)}$.

Clinical manifestations can be different in different individuals, with conditions ranging from asymptomatic infections to serious illnesses, such as Severe Acute Respiratory Syndrome (SARS), causing a high number of hospitalizations, sequel and deaths. The number of records as of December 12, 2020 was 69,808,588 cases of COVID-19 worldwide, with 1,239,157 deaths. In Brazil, the numbers were $6,781,799$ cases and 179,765 deaths ${ }^{(2)}$.

Since the onset of the COVID-19 pandemic, health professionals have been going through changes in their working hours and experiencing changes in their personal and professional lives. Nurse practitioners work on the front lines in various health sectors, contributing to the reception and screening of suspected cases, collection of material for exams, isolation guidelines, execution of care and procedures specific to hospitalization, such as hygiene, medication and airway aspiration, in addition to acting in health education, management, teaching and research actions ${ }^{(3)}$.

Several authors describe the impact on quality of life (QoL) and changes in sleep quality ${ }^{(4-5)}$ of these professionals who work directly in care ${ }^{(6-8)}$. Among the negative impacts on professionals' QoL are change in work performance and health status, which are mainly caused by psychological factors, such as stress and anxiety(7).

In addition to stress and anxiety, other factors contribute to physical and mental exhaustion, such as workload, work environment and exposure to risk factors, which results in negative effects on $\mathrm{QoL}^{(9)}$. In this context, it is noteworthy that QoL is related to individuals' understanding of their own life and their particular yearnings for the future, involving dimensions of physical and psychological health, level of independence, social relationships, environment and spiritual standard ${ }^{(10)}$.

A study carried out in India observed low QoL among health professionals, and most of them (87.0\%) were in direct care of patients with COVID-19; $43.0 \%$ had more than ten patients per day under their care ${ }^{(11)}$. In another study, also with health professionals, QoL in nurses was worse than that observed in other professionals, confirming that nurse practitioners can be more impacted in assistance of the new coronavirus pandemic ${ }^{(7)}$.

Thus, given the pandemic scenario, there is a gap with regard to the QoL of Brazilian nurse practitioners. With the increase in the workload in this period, research on QoL in the COVID-19 pandemic with nurse practitioners has been conducted in several countries, given the propensity of these professionals to change it. In this way, this study can contribute to the creation and implementation of consistent interventions for the QoL of nurse practitioners working on the front lines.

\section{OBJECTIVE}

To assess the quality of life of nurse practitioners during the COVID-19 pandemic and analyze related factors.

\section{METHODS}

\section{Ethical aspects}

This study was approved by Institutional Review Board of Instituto Federal de Educação, Ciência e Tecnologia do Sul de Minas Gerais.

\section{Study design, period, and place}

This is a cross-sectional and analytical study, guided by the STROBE ${ }^{(10)}$ tool, carried out in June and July 2020, with nurse practitioners from all regions of Brazil who worked in care.

\section{Population or sample; inclusion and exclusion criteria}

The selection of participants was done by non-probabilistic convenience sampling. Professionals aged 18 years or over, residents and working in Brazil as nursing assistants, nursing technicians or nurses and working in health care during the new coronavirus pandemic were included. Workers exclusively working at night, because these professionals are more likely to develop sleep disorders and impaired circadian rhythms, were excluded.

For the present study, a representative sample of the number of nurse practitioners working throughout the national territory was used $^{(12)}$. Adopting a sampling error of $5 \%$, a confidence level of $99 \%$ and the population's heterogeneity, a representative sample of nurse practitioners was reached, consisting of 664 people.

\section{Study protocol}

For the invitation and data collection, social media such as Facebook, Instagram, WhatsApp (individual contacts and groups of contacts) were used, as well as email, applying an online form through the Google Forms application. The online questionnaire was disseminated using the snowball technique, in which each participant was invited to disclose the research after their participation.

The data collection instrument consisted of the World Health Organization Quality of Life (WHOQOL-bref) ${ }^{(10)}$, to assess QoL, and a questionnaire to characterize the population with sociodemographic data (region of residence, gender, age, education and professional activity), working conditions (weekly workload, number of employment contracts, place of work and weekly workload) and variables that indicated changes during the pandemic (increase in the number of patients and care, increased tension and stress among on-duty team members and use of sleep medications).

The population characterization questionnaire was constructed for the study and submitted to face validation. For QoL, the questionnaire validated in Brazil was used, consisting of 26 questions, two of which were general QoL questions, and the other 24 represent each of the 24 facets that make up the original instrument. The 26 facets of the WHOQOL-bref are distributed into 4 domains: physical (assesses aspects related to pain, mobility, sleep, fatigue, daily activities and work ability), psychological (analyzes positive feelings, thinking, learning, memory and concentration, self-esteem, body image and appearance, negative feelings, spirituality/religion/personal beliefs), 
social relationships (investigates the degree of satisfaction with personal relationships, sexual activity and the network support) and environment (assesses physical safety and security, environments and opportunities to acquire new information and skills) (13-14). The questions have the option of answers in a Likert-type scale (1 to 5 points), with a score that varies between 0 and 100 points, and the higher the score, the better the QoL. In this instrument, it is necessary to recode the value of questions $3,4,26$, in which: $(1=5),(2=4),(3=3),(4=2)$ e $(5=1)$.

\section{Analysis of results, and statistics}

Data were exported from Google Forms directly to a Microsoft Office Excel ${ }^{\circ}$ spreadsheet, double-checked, and incomplete questionnaires were eliminated and transferred to the Statistical Analysis System software (version 9.4).

Data treatment was performed using descriptive statistics (measures of central tendency, position and dispersion) regarding the characterization of the sample and the distribution of scores for each domain of the WHOQOL-bref. Cronbach's alpha coefficient was calculated to verify the instrument's internal consistency (WHOQOL-bref), with values above 0.70 being considered as evidence of reliability.

To compare the categories of the variables of interest, analysis of covariance (ANCOVA) was proposed, which, in addition to comparing groups and controlling the confounding effect, allows the adjustment of covariates ${ }^{(15)}$. The significance level adopted was $5 \%(p<0.05)$.

\section{RESULTS}

In the present study, 577 questionnaires were answered, of which 5 were excluded for being incomplete. Data from 572 participants from northern, northeastern, southeastern, centerwestern, and southern Brazil were analyzed.

Cronbach's alpha coefficient for the whole WHOQOL-bref scale was 0.91. Internal reliability for all domains was above 0.70, except for the domain psychological (0.68). In relation to nurse practitioners, the mean total QoL score was 56.79 (SD=13.56), with the highest scores in the physical domain (59.77; $S D=16.47)$, followed by the domains psychological (56.37; SD=14.82), environment (55.20; $\mathrm{SD}=14.62)$ and social (54.95; $\mathrm{SD}=21.15)$ (Table 1).

Regarding participants' sociodemographic variables, it was observed that $508(88.81 \%)$ were women, with a mean age of $36.4(\mathrm{SD}=8.8)$ years, median of 35.00 and range from 19 to 65 years. As for education, 87 (15.20\%) had high school, 102 (17.8\%), graduation and 383 (67.00\%), lato sensu and/or stricto sensu graduate education. Regarding the WHOQOL-bref domains, women had lower scores for QoL scores than men.

As for professional practice, 409 (71.50\%) were nurses and had higher scores for QoL in relation to technical professionals and nursing assistants, and assistants had the lowest averages in physical and environment domains. According to the acting services, the majority (76.90\%) were in hospital units, such as Intensive Care Unit (28.70\%), medical clinic (17.30\%), emergency (10.50\%) and other sectors (20.50\%); and $23.10 \%$ were in extra-hospital health services.

For workload, 262 (45.80\%) participants who worked from 31 to 40 hours per week predominated. Regarding the WHOQOLbref, nurse practitioners with working hours of 20 to 30 hours a week had higher scores in physical and environment domains and lower scores for working hours of 50 hours or more in physical, psychological and social domains. Regarding the employment relationship, 396 (69.20\%) reported a single job, which had higher scores for QoL in physical, social and environment domains.

Regarding changes in work, staff and sleep after the onset of the COVID-19 pandemic, 462 (80.80\%) mentioned an increase in the number of patients assisted and in care, 561 (98.10\%) noticed an increase in tension and stress among team members, and 148 (25.90\%) started using sleep medication, who had higher scores for QoL in relation to the physical domain (Table 2).

Table 3 refers to analysis of covariance of WHOQOL-bref domains, in which the results show an increase in the estimate of the mean difference in QoL in the physical domain, with two or more jobs and a decrease in the mean QoL for higher workload to 50 hours, in the increase of patients and care, tension and stress among team members and in the use of medication to sleep.

In psychological and social domains, there was a decrease in the estimate of the mean difference in QoL for workloads greater than 50 hours and in the use of medications for sleeping. In the social domain, there was still a decrease in the estimate of the mean difference in QoL in the increase in patients and care. Regarding the environment domain, there was an increase in the estimate of the mean difference in QoL of nurses in relation to nursing assistants and a decrease in technicians in relation to nurses, in the increase of patients and care, tension and stress among team members and in the use of sleep medications.

With statistical significance, the relationship and variables with WHOQOL-bref domains were: profession, weekly workload, work relationship, increase in the number of patients and care after the pandemic, increased tension and stress in the on-call team in the pandemic and having started to use medication to sleep in the pandemic.

Table 1 - Descriptive analysis of quality of life scores (WHOQOL-bref) of nurse practitioners ( $n=572)$, Brazil, 2020

\begin{tabular}{|c|c|c|c|c|c|}
\hline Domains & Mean & Standard deviation & $\begin{array}{l}\text { WHOQOL-bref } \\
\text { Minimum }\end{array}$ & Median & Maximum \\
\hline Physical & 59.77 & 16.47 & 10.71 & 60.71 & 100 \\
\hline Psychological & 56.37 & 14.82 & 16.67 & 58.33 & 91.67 \\
\hline Social & 54.95 & 21.15 & 0.00 & 58.33 & 100 \\
\hline Environment & 55.20 & 14.62 & 3.13 & 56.25 & 90.63 \\
\hline Total score & 56.79 & 13.56 & 12.50 & 57.29 & 91.67 \\
\hline
\end{tabular}

WHOQOL-bref - World Health Organization Quality of Life - abbreviated version. 
Table 2 - Distribution of nurse practitioners according to the responses in quality of life domains (WHOQOL-bref), ( $\mathrm{n}=572)$, Brazil, 2020

\begin{tabular}{|c|c|c|c|c|c|}
\hline \multirow[b]{2}{*}{ Variables } & \multirow[b]{2}{*}{ n (\%) } & \multicolumn{4}{|c|}{ WHOQOL-bref } \\
\hline & & $\begin{array}{l}\text { Physical domain } \\
\text { Mean (SD) }\end{array}$ & $\begin{array}{l}\text { Psychological domain } \\
\text { Mean (SD) }\end{array}$ & $\begin{array}{l}\text { Social domain } \\
\text { Mean (SD) }\end{array}$ & $\begin{array}{l}\text { Environment domain } \\
\text { Mean (SD) }\end{array}$ \\
\hline \multicolumn{6}{|l|}{ Sex } \\
\hline Female & $508(88.80)$ & $59.62(16.66)$ & $56.17(14.92)$ & $54.74(21.20)$ & $54.90(14.56)$ \\
\hline Male & $64(11.20)$ & $60.94(14.98)$ & $58.01(14.01)$ & $56.64(20.80)$ & $57.57(15.03)$ \\
\hline \multicolumn{6}{|l|}{ Profession } \\
\hline Nurse & 409 (71.50) & $60.25(16.32)$ & $56.72(14.70)$ & $55.89(21.10)$ & $57.09(14.06)$ \\
\hline Nursing technician & $149(26.10)$ & $58.70(16.59)$ & $55.45(15.46)$ & $52.52(21.81)$ & $50.69(15.41)$ \\
\hline Nursing assistant & $14(2.50)$ & $56.89(19.73)$ & $55.95(11.75)$ & $53.57(12.54)$ & $47.99(9.22)$ \\
\hline \multicolumn{6}{|l|}{ Weekly workload } \\
\hline 20 to 30 hours & $69(12.10)$ & $62.58(16.85)$ & $57.31(15.30)$ & $56.16(21.42)$ & $57.47(14.51)$ \\
\hline 31 to 40 hours & $262(45.80)$ & $61.45(16.48)$ & $57.47(14.46)$ & $56.58(20.17)$ & $54.64(13.95)$ \\
\hline 41 to 50 hours & $115(20.10)$ & $59.04(15.73)$ & $55.22(15.31)$ & $55.00(22.39)$ & $55.38(15.56)$ \\
\hline 50 hours or more & $126(22.00)$ & $55.39(16.17)$ & $54.63(14.79)$ & $50.86(21.34)$ & $54.96(15.22)$ \\
\hline \multicolumn{6}{|l|}{ Work relationship } \\
\hline One & $396(69.20)$ & $60.02(17.06)$ & $56.31(14.91)$ & $55.77(21.00)$ & $55.30(14.86)$ \\
\hline Two or more & $176(30.80)$ & $59.19(15.08)$ & $56.51(14.68)$ & $53.12(21.43)$ & $54.97(14.12)$ \\
\hline \multicolumn{6}{|c|}{$\begin{array}{l}\text { Increase in the number of patients and } \\
\text { care in the pandemic }\end{array}$} \\
\hline Yes & $462(80.80)$ & $58.47(15.71)$ & $55.87(14.01)$ & $53.93(20.88)$ & $53.77(14.21)$ \\
\hline No & $110(19.20)$ & $65.19(18.45)$ & $58.48(17.46)$ & $59.24(21.81)$ & $61.19(14.88)$ \\
\hline \multicolumn{6}{|c|}{$\begin{array}{l}\text { Increased tension and stress in the on- } \\
\text { call team in the pandemic }\end{array}$} \\
\hline Yes & $561(98.10)$ & $59.48(16.27)$ & $56.25(14.75)$ & $54.9(21.1)$ & $54.97(14.54)$ \\
\hline No & $11(1.90)$ & $74.35(20.50)$ & $62.5(17.97)$ & $57.58(24.57)$ & 67.05 (14.55) \\
\hline \multicolumn{6}{|c|}{$\begin{array}{l}\text { Started using medication to sleep in the } \\
\text { pandemic }\end{array}$} \\
\hline Yes & $148(25.90)$ & $50.41(15.28)$ & $50.08(14.26)$ & $49.77(21.58)$ & $50.34(15.39)$ \\
\hline No & $424(74.10)$ & $63.03(15.61)$ & 58.57 (14.39) & $56.76(20.72)$ & $56.90(13.97)$ \\
\hline
\end{tabular}

WHOQOL-bref - World Health Organization Quality of Life - abbreviated version; SD - standard deviation.

Table 3 - Analysis of covariance of sociodemographic and work variables and changes reported during the pandemic, with WHOQOL-bref domains in nurse practitioners $(n=572)$, Brazil, 2020

\begin{tabular}{|c|c|c|c|c|c|c|c|c|}
\hline \multirow{3}{*}{ Variables } & \multicolumn{8}{|c|}{ WHOQOL-bref } \\
\hline & \multicolumn{2}{|c|}{ Physical domain } & \multicolumn{2}{|c|}{ Psychological domain } & \multicolumn{2}{|c|}{ Social domain } & \multicolumn{2}{|c|}{ Environment domain } \\
\hline & DM & $\mathbf{C l}^{\mathbf{c}}$ & DM & $\mathbf{C l}$ & DM & $\mathbf{C l}$ & DM & $\mathbf{C l}$ \\
\hline \multicolumn{9}{|l|}{ Sex } \\
\hline Female (vs male) & -2.11 & $-6.12 ; 1.89$ & -2.09 & $-5.90 ; 1.71$ & -3.07 & $-8.61 ; 2.46$ & -2.50 & $-6.17 ; 1.15$ \\
\hline \multicolumn{9}{|l|}{ Profession } \\
\hline Nurse (vs assistant) & 4.56 & $-3.78 ; 12.91$ & 0.21 & $-7.71 ; 8.15$ & 1.98 & $-9.54 ;-13.50$ & 11.33 & $3.70 ; 18.95^{*}$ \\
\hline Technician (vs nurse) & -1.24 & $-4.11 ; 1.62$ & -1.00 & $-3.72 ; 1.72$ & -3.31 & $-7.27 ; 0.65$ & -6.04 & $-8.66 ;-3.42 *$ \\
\hline Technician (vs assistant) & 3.32 & $-5.26 ; 11.91$ & -0.78 & $-8.94 ; 7.37$ & -1.32 & $-13.18 ; 10.53$ & 5.29 & $-2.55 ; 13.13$ \\
\hline \multicolumn{9}{|l|}{ Weekly workload } \\
\hline $\begin{array}{l}\text { Greater than } 50 \text { hours (vs } 20 \text { to } 30 \\
\text { hours) }\end{array}$ & -11.40 & $-16.63 ;-6.16^{*}$ & -5.17 & $-10.15 ;-0.20^{*}$ & -7.12 & $-14.35 ; 0.10$ & -4.44 & $-9.23 ; 0.33$ \\
\hline $\begin{array}{l}\text { Greater than } 50 \text { hours (vs } 31 \text { to } 40 \\
\text { hours) }\end{array}$ & -9.92 & $-14.24 ;-5.58^{*}$ & -5.11 & $-9.22 ;-0.99 *$ & -7.25 & $-13.22 ;-1.28^{*}$ & -0.77 & $-4.72 ; 3.18$ \\
\hline $\begin{array}{l}\text { Greater than } 50 \text { hours (vs } 41 \text { to } 50 \\
\text { hours) }\end{array}$ & -6.99 & $-11.45 ;-2.52^{*}$ & -2.66 & $-6.90 ; 1.57$ & -5.60 & $-11.76 ; 0.55$ & -1.66 & $-5.74 ; 2.41$ \\
\hline 41 to 50 hours (vs 20 to 30 hours) & -4.41 & $-8.96 ; 0.14$ & -2.51 & $-6.83 ; 1.81$ & -1.51 & $-7.79 ; 4.76$ & -2.78 & $-6.94 ; 1.37$ \\
\hline 41 to 50 hours (vs 31 to 40 hours) & -2.92 & $-6.30 ; 0.46$ & -2.44 & $-5.65 ; 0.77$ & -1.64 & $-6.31 ; 3.02$ & 0.89 & $-2.19 ; 3.98$ \\
\hline 31 to 40 hours (vs 20 to 30 hours) & -1.48 & $-5.52 ; 2.55$ & -0.06 & $-3.90 ; 3.77$ & 0.13 & $-5.44 ; 5.70$ & -3.67 & $-7.36 ; 0.01$ \\
\hline \multicolumn{9}{|l|}{ Work relationship } \\
\hline Two or more (vs one) & 5.25 & $1.60 ; 8.90^{*}$ & 3.02 & $-0.44 ; 6.48$ & 1.55 & $-3.48 ; 6.56$ & 0.915 & $-2.41 ; 4.24$ \\
\hline \multicolumn{9}{|l|}{$\begin{array}{l}\text { Increase in the number of patients and } \\
\text { care in the pandemic }\end{array}$} \\
\hline Yes (vs no) & -5.61 & $-8.83 ;-2.38^{*}$ & -1.94 & $-5.01 ; 1.11$ & -4.87 & $-9.33 ;-0.42^{*}$ & -6.40 & $-9.34 ;-3.45^{*}$ \\
\hline \multicolumn{9}{|l|}{$\begin{array}{l}\text { Increased tension and stress in the on-call } \\
\text { team in the pandemic }\end{array}$} \\
\hline Yes (vs no) & -11.83 & $-21.25 ;-2.40^{*}$ & -4.06 & $-13.02 ; 4.88$ & 1.15 & $-11.85 ; 14.16$ & -9.66 & $-18.27 ;-1.05^{*}$ \\
\hline \multicolumn{9}{|l|}{$\begin{array}{l}\text { Started using medication to sleep in } \\
\text { the pandemic }\end{array}$} \\
\hline Yes (vs no) & -11.34 & $-14.22 ;-8.47^{*}$ & -7.93 & $-10.67 ;-5.20^{*}$ & -6.11 & $-10.08 ;-2.14^{*}$ & -5.30 & $-7.92 ;-2.67^{*}$ \\
\hline
\end{tabular}




\section{DISCUSSION}

Regarding the sociodemographic profile of nurse practitioners, there was a predominance of women, nurses, those with an employment relationship and a weekly workload of 31 to 40 hours. These results are similar to another study carried out in Brazil, which investigated the prevalence and factors associated with anxiety and depression in nurse practitioners who worked in coping with COVID-19, in which females predominated, with higher education or postgraduate studies, only one employment relationship and work regime of 40 hours per week ${ }^{(7)}$. A similar profile was also described in a study carried out in Wuhan, China, with professionals working in hospitals ${ }^{(14)}$, showing that nurses are the most predominant on the front line of the new coronavirus and the population most vulnerable to the consequences of the pandemic.

With regard to the results of applying the QoL questionnaire, the WHOQOL-bref showed good reliability through the online form (Cronbach's alpha), confirming that the instrument was valid and reliable for assessing the QoL of the study sample. It is noteworthy that QoL is self-reported and, therefore, subjective and temporary, being directly related to the context experienced at the time.

Considering the role that nurse practitioners play in combating COVID-19, QoL assessment should be considered with a view to preventing damage to professionals' physical and mental health, in addition to contributing to improving the care provided. Despite being a recurrent theme in research, it is still neglected by professionals, co-workers and managers ${ }^{(15-16)}$. In this study, the mean scores of QoL domains were low for all nurse practitioners, especially for technicians and assistants.

An important finding of this study is that, in addition to the repercussions in physical, psychological and social domains, the environment domain was related to the profession, with a decrease in QoL for the category of nursing assistants and technicians and low perception of QoL for an increase in patients and care, with increased tension and stress in the team and the use of sleep medications with the pandemic. Lower perception of QoL among nursing assistants and technicians could be justified only by the lower qualification of these workers, when compared to graduated professionals. However, short training, associated with the large offer of courses in the country, increase the possibility of professionalization, but reduce wage appreciation, which, added to the unworthy conditions of dimensioning, long working hours and stressful environments, especially in the pandemic of COVID-19, could explain the findings of this study ${ }^{(16-18)}$.

In the analysis of participants' QoL, it was observed that the global mean score was relatively low (56.79 points). The physical domain was the one with the greatest distribution of means and median scores for QoL; however, it is still far from being considered of good quality, which may be linked to the perception of financial satisfaction and the availability of energy and mobility conditions for activities of daily living and for work ${ }^{(14)}$, evidenced by the increase in QoL scores for those who had two or more employment contracts, being a reality for nurse practitioners in the country, due to the low wages of the category ${ }^{(18)}$. However, weekly hours of more than 50 hours, increase in the number of patients and care, tension, stress on the health team and taking sleep medication were associated with the perception of worse QoL.
With the rapid increase in the number of patients and the low supply of health services, the pandemic increased the number of patients assisted, the time spent with patients and work overload. Nurse practitioners, as they are on the front line of services and also of COVID-19 care, became more subject to isolation and discrimination, becoming more prone to physical fatigue, emotional disturbances and sleep problems ${ }^{(19-21)}$. The increase in physical and emotional burden, in addition to impacting the relationships between the team, also harm professionals' health, such as quality of sleep and rest, which justifies the increase in the consumption of sleep medications, described in this study.

Coping with the new coronavirus results in physical and psychological aspects of nurse practitioners, translated by the perception of negative feeling $\mathrm{s}^{(14)}$. The increase in working hours of more than 50 hours a week and having started to use medication to sleep after the onset of the pandemic were indicators of a worse perception of QoL, confirming signs of emotional changes linked to long and stressful working hours and difficulty to sleep.

In a study that investigated the QoL of health professionals who worked in COVID-19care in Turkey, it was noticed that, in the face of crises, working hours could increase, intensifying contact with patients, with the team and increasing the risk of transmission and death ${ }^{(7)}$, which can justify the lower perception of QoL with long working hours. However, the increase in working hours can impact professionals' mental health, increasing the levels of depression, sleep disturbance and symptoms of anxiety, compared to other health professionals ${ }^{(16)}$, corroborating the increase in the use of sleep medications, found in this study.

The social domain showed a reduction in QoL with an increase in weekly workload of more than 50 hours, an increase in patients and care, and also in the use of sleep medications by professionals after the onset of the pandemic. It is known that, in addition to the increase in workload, changing personal and family relationships and the search for support ${ }^{(19)}$, health professionals, directly and indirectly involved in fighting the pandemic, constitute a risk group for COVID-19 because they are daily exposed to infected patients and the risk of becoming ill. Thus, in addition to distancing measures, which interfered in family and social relationships, the use of protective equipment throughout the working day, preserving professionals from contact with patients, but also with other colleagues, had an impact on relationships of affection and interpersonal support among the team ${ }^{(22)}$.

In addition to the weakening of personal relationships, with the increase in the number of patients and care, many services experienced lack of beds to serve all patients and the absence of personal protective equipment or low quality of supplies made available ${ }^{(19)}$, leading to fear and insecurity in the face of care, which could justify professionals' worse perception of QoL regarding the institutional support network. Thus, in addition to the repercussions in physical, psychological and social domains, the environment domain was related to the profession, with an increase in QoL for the category of nurses and a low perception of QoL for the increase in patients and care, with increased tension and stress on staff and use of sleeping medications with the pandemic.

A study carried out in Turkey, which assessed the level of anxiety, sleep quality and QoL of health professionals at a hospital, identified that, in health services that work in the pandemic, professionals 
may have mental health problems that can affect attention, understanding and decision-making capacity, having a long-term effect on health professionals' levels of well-being and working relationships ${ }^{(7,23)}$. Thus, symptoms of tension, stress and anxiety are directly involved for health professionals, especially nurses ${ }^{(24)}$.

Some factors explain lower levels of anxiety in health professionals from some countries when compared to others, including service management planning. Planning, which may be linked to a higher level of education, includes better institutional support provided, with the provision of satisfactory human and material resources, which ensures greater safety for professionals and, consequently, lower levels of stress, anxiety and tension ${ }^{(7)}$.

Thus, the better perception of QoL in relation to the professional category may be linked to the higher level of education of professional nurses and the number of postgraduate participants $(67 \%)$ in this study. This finding corroborates a study, which points to a relationship between worse QoL and low education in nurse practitioners working in hospital services ${ }^{(22)}$ and health service users ${ }^{(25)}$, which may justify the strong relationship between the level of education and the fact that nurses have presented better QoL in relation to nursing assistants.

The total number of nurse practitioners working in the hospital points to the high risk to which these professionals are exposed. However, health professionals still face the stigma for working with COVID-19 patients, longer working hours, increased number of patients and care and the use of strict safety measures, which impact on autonomy, self-care, decreasing the interaction and social support ${ }^{(14,24)}$.

The work of nurse practitioners with patients with COVID-19 increases the risk of occupational exposure. The increase in tension and stress among health care team members is already predicted and described in other national ${ }^{(18,22)}$ and international studies ${ }^{(14,21)}$, which point to general stressors, such as the risk of infection, misinterpretation of symptoms of other diseases, concern for the family, in addition to the fear of falling ill, isolation, death and dying, which affect everyone.

The greater the number of patients, the greater the workload, which increases the possibility of infection and physical exhaustion, resulting in greater stress ${ }^{(5,26-27)}$ and burnout ${ }^{(28)}$, which affects the quality of sleep, leading to medication use $\mathrm{e}^{(16,19,21)}$. However, another aspect to be highlighted is that most participants were women who, in addition to work, assumed the responsibility of household chores, reducing free time for recreation and leisure activities, which may have negatively interfered in this domain of $\mathrm{QoL}^{(18,29)}$.

\section{Study limitations}

As a limitation of this study, a cross-sectional design can be pointed out, which prevents the assessment of the influence of variables over time. The second is the fact that participants may have answered the questions during or after a stressful workday, which may have influenced the result, interfering with the proper judgment of changes that occurred after the pandemic. The third was the construction of questionnaires designed in a more succinct and objective way, in order to obtain a greater range of respondents, which may have suppressed some important questions that could interfere with the outcome variables. The fourth is the fact that data collection took place online, which may not have reached all nurse practitioners, as not all of them have internet access. The fifth is that the sample size was not reached, which may have influenced the study's analyses. However, as mitigating factors, the use of an established and widely used instrument in the literature, the recognized importance of assessing QoL, the congruence with other authors and the evidence of satisfactory internal consistency Cronbach's alpha greater than 0.70 for physical, social and environment domains.

\section{Contributions to nursing}

Given the relevance and the few national studies that deal with this issue, it is believed that the available evidence will contribute to the Brazilian scientific production on QoL in nurse practitioners in coping with COVID-19, pointing to the importance of preventing and reducing stressful factors, organizing the necessary information and training activities, reducing the workload and increasing social support mechanisms, to achieve greater satisfaction and motivation of professionals and the improvement in conditions that negatively affect QoL and that directly impact the quality of nursing care.

\section{CONCLUSIONS}

Nurse practitioners have a special role to play in facing this crisis as part of the current COVID-19 pandemic. However, there are factors that are associated with decreased QoL of professionals and that impact the quality of care provided.

The perception of QoL of the analyzed nurse practitioners showed that the social domain reflected the worst score in the assessment, indicating that participants considered having some difficulty related to satisfaction with personal relationships, sexual activity and support network. The scores related to the global QoL domain, and to physical, psychological and environment domains obtained similar results, demonstrating homogeneity between these aspects in the lives of the analyzed nurse practitioners.

The variables that were related to QoL were profession, number of employment contracts, weekly workload, increase in patients and care, tension and stress and the use of medications to sleep.

Once QoL is assessed, the multidisciplinary team and managers can propose interventions to act on potentially modifiable factors, personal and of the work environment, with a view to reducing the harm to nurse practitioners' health and contributing to the quality of care provided.

Thus, despite the pandemic bringing expected changes to circumstances, such as an increase in the number of patients, an increase in the complexity of cases and fear of contamination, normalization of psychological stress, social support, clear communication and division of tasks, and flexible ways of designing and using stigma-free care seem to be particularly important measures that need to be applied.

\section{ACKNOWLEDGMENT}

This study was financed in part by the Coordenação de Aperfeiçoamento de Pessoal de Nível Superior - Brasil (CAPES) - Finance Code 001 and Federal Institute of Education, Science and Technology of South of Minas Gerais - IFSULDEMINAS. 


\section{REFERENCES}

1. LiT. Diagnosis and clinical management of severe acute respiratory syndrome coronavirus 2 (SARS-CoV-2) infection: an operational recommendation of Peking union medical college hospital (V2.0). Emerg Microbes Infect. 2020;9(1):582-5. https://doi.org/10.1080/22221751.2020.1735265

2. World Health Organization. Coronavirus disease (COVID-19): dashboard [Internet]. 2020 [cited 2020 Nov 10]. Available from: https://covid19.who.int/

3. Choi KR, Jeffers KS, Logsdon MC. Nursing and the novel coronavirus: risks and responsibilities in a global outbreak [Editorial]. J Adv Nurs. 2020;76(7):1486-7. https://doi.org/10.1111/jan.14369

4. Jahrami H, BaHammam AS, AlGahtani H, Ebrahim A, Faris M, AlEid K, et al. The examination of sleep quality for frontline healthcare workers during the outbreak of COVID-19. Sleep Breath. 2020:25(1):503-11. https://doi.org/10.1007/s11325-020-02135-9

5. Huang L, Lei W, Liu H, Hang R, Tao X, Zhan Y. Nurses'sleep quality of "Fangcang" hospital in China during the COVID-19 pandemic. Int J Ment Health Addict. 2020;1-11. https://doi.org/10.1007/s11469-020-00404-y

6. Buselli R, Corsi M, Baldanzi S, Chiumiento M, Del Lupo E, Dell'Oste V, et al. professional quality of life and mental health outcomes among health care workers exposed to Sars-Cov-2 (Covid-19). Int J Environ Res Public Health. 2020;17(17):6180. https://doi.org/10.3390/ijerph17176180

7. Korkmaz S, Kazgan A, Çekiç S, Tartar AS, Balcı HN, Atmaca M. The anxiety levels, quality of sleep and life and problem-solving skills in healthcare workers employed in COVID-19 services. J Clin Neurosci. 2020;80:131-6. https://doi.org/10.1016/j.jocn.2020.07.073

8. Stojanov J, Malobabic M, Stanojevic G, Stevic M, Milosevic V, Stojanov A. Quality of sleep and health-related quality of life among health care professionals treating patients with coronavirus disease-19. Int J Soc Psychiatry. 2021;67(2):175-81. https://doi.org/10.1177/0020764020942800

9. Dal'Bosco EB, Floriano LSM, Skupien SV, Arcaro G, Martins AR, Anselmo ACC. Mental health of nursing in coping with COVID-19 at a regional university hospital. Rev Bras Enferm. 2020;73(Suppl 2):e20200434. https://doi.org/10.1590/0034-7167-2020-0434

10. World Health Organization. The world health organization quality of Life assessment (WHOQOL): position paper from the World Health Organization. Soc Sci Med. 1995:41(10):1403-9. https://doi.org/10.1016/0277-9536(95)00112-k

11. Suryavanshi N, Kadam A, Dhumal G, Nimkar S, Mave V, Gupta A, et al. Mental health and quality of life among healthcare professionals during the COVID-19 pandemic in India. Brain Behav. 2020;10:e01837. https://doi.org/10.1002/brb3.1837

12. Conselho Federal de Enfermagem. COVID-19 [Internet]. 2020 [cited 2020 Nov 10]. Available from: http://www.cofen.gov.br/enfermagem-em-numeros

13. Malta M, Cardoso LO, Bastos Fl, Magnanini MMF, Silva CMFP. STROBE initiative: guidelines on reporting observational studies. Rev Saude Publica. 2010;44(3):559-65. 10. https://doi.org/1590/S0034-89102010000300021

14. Fleck MPA, Louzada S, Xavier M, Chachamovich E, Vieira G, Santos L, et al. Aplicação da versão em português doinstrumento abreviado de avaliação da qualidade de vida“WHOQOL-bref". Rev Saude Publica. 2000;34(2):178-83. https://doi.org/10.1590/S0034-89102000000200012

15. Montgomery DC. Design and analysis of experiments. 5a ed. New York: John Wiley \& Sons, Inc.; 2010.

16. Lai J, Ma S, Wang Y, Cai Z, Hu J, Wei N, et al. Factors associated with mental health outcomes among mental care workers exposed to coronavirus disease 2019. JAMA Netw Open. 2020;3(3):e203976. https://doi.org/10.1001/jamanetworkopen.2020.3976

17. Backes MTS, Higashi GDC, Damiani PR, Mendes JS, Sampaio LS, Soares GL. Working conditions of Nursing professionals in coping with the Covid-19 pandemic. Rev Gaucha Enferm. 2021;42(esp):e20200339. https://doi.org/10.1590/1983-1447.2021.20200339

18. Souza RF, Rosa RS, Picanço CM, Souza Jr EVS, Cruz DP, Guimarães FEO, et al. Repercussões dos fatores associados à qualidade de vida em enfermeiras de unidades de terapia intensiva. Rev Salud Publica. 2018,20(4):453-59. https://doi.org/10.15446/rsap.V20n4.65342

19. Liu S, Yang L, Zhang C, Xiang Y-T, Liu Z, Hu S, et al. Online mental health services in China during the COVID-19 outbreak. Lancet Psychiatry. 2020;7(4):e17-8. https://doi.org/10.1016/S2215-0366(20)30077-8

20. Petzold MB, Plag J, Ströhle A. [Dealing with psychological distress by healthcare professionals during the COVID-19 pandemia]. Nervenarzt. 2020;91(5):417-421. https://doi.org/10.1007/s00115-020-00905-0. German

21. Ferrán MB, Barrientos-Trigo SB. [Caring for the caregiver: the emotional impact of the coronavirus epidemic on nurses and other health professionals]. Enferm Clin (England Ed). 2021;31:S35-9. https://doi.org/10.1016/j.enfcli.2020.05.006 Spanish

22. Teixeira CFS, Soares CM, Souza EA, Lisboa ES, Pinto ICM, Andrade LR, et al. The health of healthcare professionals coping with the Covid-19 pandemic. Cienc Saude Colet. 2020;25(9):3465-74. https://doi.org/10.1590/1413-81232020259.19562020

23. Kang L, Li Y, Hu S, Chen M, Yang C, Yang BX, et al. The mental health of medical workers in Wuhan, China dealing with the 2019 novel coronavirus. Lancet Psychiatry. 2020;7(3):e14. https://doi.org/10.1016/S2215-0366(20)30047-X

24. Magnago TSBS, Lisboa MTL, Griep RH, Kirchhof ALC, Camponogara S, Nonnenmacher CQ et al. Nursing workers: work conditions, social-demographic characteristics and skeletal muscle disturbances.. Acta Paul Enferm. 2010;23(2):187-93. https://doi.org/10.1590/S0103-21002010000200006

25. Almeida-Brasil CC, Silveira MR, Silva KR, Lima MG, Faria CDCM, Cardoso CL, et al. Quality of life and associated characteristics: application of WHOQOLBREF in the context of primary health care. Cienc Saude Colet. 2017;22(5):1705-16. https://doi.org/10.1590/1413-81232017225.20362015

26. Paiano M, Jaques AE, Nacamura PAB, Salci MA, Radovanovic CAT, Carreira L. Mental health of healthcare professionals in China during the new coronavirus pandemic: an integrative review. Rev Bras Enferm. 2020;73(suppl 2):e20200338. https://doi.org/10.1590/0034-7167-2020-0338 
27. Duarte MLC, Silva DG, Bagatini MMC. Nursing and mental health: a reflection in the midst of the coronavirus pandemic. Rev Gaucha Enferm. 2021;42(spe):e20200140. https://doi.org/10.1590/1983-1447.2021.20200140

28. Liu Y, Aungsuroch Y. Work stress, perceived social support, self-efficacy and burnout among Chinese registered nurses. J Nurs Manag. 2019;27(7):144553. https://doi.org/10.1111/jonm.12828

29. Moreira WC, Sousa AR, Nóbrega MPSS. Mental illness in the general population and health professionals during covid-19: a scoping review. Texto Contexto Enferm. 2020;29:e20200215. https://doi.org/10.1590/1980-265x-tce-2020-0215 